\title{
The Meaning of Burning Incense Ritual as a Preservation of Cultural Values and Beliefs of the Community of Nagan Raya-Aceh
}

\author{
${ }^{* 1}$ Muzakkir, ${ }^{2}$ Rena Juliana, ${ }^{3}$ Reni Juliani \\ ${ }^{1}$ Universitas Teuku Umar, Indonesia, muzakkir@utu.ac.id \\ ${ }^{2}$ STAIN Teungku Dirundeng Meulaboh, Indonesia, renajuliana@staindirundeng.ac.id \\ ${ }^{3}$ Universitas Teuku Umar, Indonesia, renijuliani@utu.ac.id
}

Submitted: 02/04/2021 Revised: 10/04/2021 Accepted: 05/05/2021

How to cite this article: Muzakkir, Juliana, R \& Juliani, R. (2021). The meaning of burning incense ritual as a preservation of cultural values and beliefs of the community of Nagan Raya-Aceh. Journal of Education, Language and Religion. 3 (1), 1-8.

\begin{abstract}
The ritual of burning incense at Gudang Buloh Mosque, which has existed for hundreds of years, is still upheld by the community of Nagan Raya. This ritual is an ancestral tradition from time to time that has been carried out from generation to generation until now it has been developing in some people in the southwest region of Aceh. The purpose of this study was to investigate the meaning of the burning incense ritual at Gudang Buloh Mosque to the people. This research method is qualitative. The researchers went to the site to collect data. After the researchers made observations, received data from various sources, and interviews, the researcher analyzed them to use as study material. The research site is located in the Syeikh Syaikhuna Gudang Buloh mosque, Ujong Pasie village, Kuala district, Nagan Raya Reign, Aceh Province. The results showed that; First, the ritual of burning incense in the mosque, which is a legacy of the past to this day, is still preserved and has even evolved and become the beliefs of some people in and around it. Second, the ritual of burning incense is guided by the Khadam of the mosque to every community who has a desire so that the ceremony is believed to contain sacred values. Third, from the perspective of social communication, the ritual of burning incense is at the same time a process of socialization for the transmission of ancient values that are exalted by society, and through social communication, the consciousness of the community can build a fraternal bond that what the community believes can be achieved. Based on this belief, the ritual of burning incense is maintained.
\end{abstract}

\section{Keywords}

Meaning; Burning Incense Ritual; Cultural Values; Beliefs: The Community of Nagan Raya-Aceh

\section{Introduction}

In shaping and developing culture, a human can not escape the components of life, which are also the building blocks of culture, one of which is religion (Tilaar, 1999: 38). Religious education has had a major impact on uniting people's perception of a ritual perspective. Religion and culture cannot stand alone in human life. Religion and culture have a very close relationship in the dialectic; aligned to create and then negate one another. Religion is a guideline for human life created by God, while culture is a habit of the way of life of people, created by humans themselves, based on the results of 
creativity, taste, and character given by God. Religion and culture influence each other. Religion influences culture, community groups, and ethnic groups (Bauto, 2014: 24).

Culture is passed down from previous generations to future generations through the ways of behaving. Thus culture is born through the process of education and also through the process of everyday social life. Humans live and develop very much depending on the culture that has been created. Humans create a culture to meet their needs. It should be noted, humans, in general, must carry out ritual traditions in their lives, for example, the rituals of celebrating holidays, weddings, and even burning incense as a symbol to relinquish one's desire, which can create interactions between humans. Humans who were created by Allah SWT have the instinct and human nature to serve Him as the creator.

Ritual is a symbol of obedience and submission to something. This obedience can be reflected in the struggles of religious followers to receive "reward" or enjoyment after death (Aziza, 2016: 3). All forms of ritual are communicative. In social situations, ritual is always symbolic behavior. Rituals are therefore always a way of conveying something (Setawati, 2019: 439).

Culture and communication are inextricably linked, because culture not only determines who speaks to whom, what, and how people encrypt messages, but also the meaning they have for messages and the conditions for sending, watching, and interpreting messages. The entire repertoire of human behavior depends heavily on the culture in which they grew up. Culture is therefore the basis of communication. If there are different cultures, there are also different communication practices (Aw, 2015: 69).

Society is a unity of human life that interacts according to a certain system of customs that is continuous and is bound by a sense of common identity. Continuity is a community unit that has four characteristics, namely: 1) Interaction between citizens; 2) Customs; 3) Continuity of time; 4) A strong sense of identity that binds all citizens (Koentjaningrat, 2009: 115).

Some people, when they hear the word incense, imagine mystical things. It is possible that this assumption is not wrong, as there have been constructs for several generations that shape people's view of incense through both visual and other media. There is a mystical impression when we smell incense or see other people burning incense. This impression does not exist in itself, but through a long and orderly process in the continuity of social life.

Incense is a tree that grows in the wilderness and is often found in lowland forests and mountainous areas such as the Minangkabau. In the book written by Heyne, it is stated that the sailors of the Middle East stated that incense flourished at an altitude of 900-1200 meters above sea level. Incense has been traded in the Arabian Peninsula and North Africa in ancient times for more than 5000 years (Susanti, 2018: 3).

Incense, also known as Frankincense, Olibanum, Salai Guggal, or Boswellia Serrata, is no stranger to us, especially to adherents of the local culture. An object in the form of a brown or white cloudy crystal is usually burned to accompany both personal and public rituals (Harahap and Harahap, 2019: 64).

The Aceh culture cannot be separated from Islam. In its history, Aceh developed into a center for Islamic studies in the 16th century (Hadi, 2010: 32). Hence, many countries outside of Aceh have come to Aceh to study Islam. Islam's resilience in Aceh has also influenced the ancestral culture of the people of Aceh, so it is not surprising that Aceh's cultural traditions are influenced by Islam. The people of Aceh are very fanatical about their customs. The culture and customs of Aceh are nothing more than the norms of Islam itself. Islamic culture and teaching have interacted and assimilated harmoniously in Aceh society for hundreds of years (Nurdin, 2013: 139).

Rural communities are people who are still attached to traditions or habits that make these habits a part of the culture in social life, such as the Acehnese people in Nagan Raya Regency who have a tradition of burning incense at the Gudang Buloh Mosque. Sztompka (2008: 69) explains that tradition is all 
material objects and ideas that come from the past but still exist today, have not been destroyed, thrown away, or forgotten.

Incense is widely used in the Acehnese cultural traditions, not only for fragrances but also believed to fulfill one's desires and achieve a good effect. There is another opinion that some Muslim communities consider incense to be associated with the practices of shirk. This assumption continues to be made, so incense is rarely used except in certain communities and under certain conditions.

This view is considered wrong as incense is not part of worship. Incense is only used to help people concerning rituals, for example, to relieving one's cravings, which is accompanied by smoking therapy with incense after burning and then rubbing on a child's head. Because through the smoked incense therapy, some people believe that it can have a healing effect on a child's illness so far.

Beyond these assumptions, incense also has a story of its own. Through religious, social, and cultural understanding, incense is valuable to some people and contains a sacred meaning. So that the ritual of burning incense at the Gudang Buloh Mosque is still practiced today by the community, which is expected not to fade over a long period time and is in a different area of life and a modern lifestyle. This is the basis of this research, which was carried out to investigate the meaning of the ritual of burning incense at the Gudang Buloh Mosque to the community of Nagan Raya Regency.

\section{Method}

This type of research is a qualitative case study approach. The case study in this research is a case study of social communication between people giving up their thirst and the Khadam of the mosque as the party leading the burning incense procession. The location of this research is in the Sheikh Syaikhuna Mosque better known as the Gudang Buloh Mosque, Nagan Raya Regency. Data collection using techniques, namely: (a) in-dept interview, (b) participant observation, and (c) documentary or literature study. The data were analyzed in several stages, namely: (1) data reduction, (2) display data, (3) conclusion drawing.

\section{Results}

The results showed that the people who gave up their wish in Sheikh Syaikhuna Gudang Buloh Mosque, Nagan Raya Regency, were very different. Some people want to be kept away from ghosts. Most of them want to recover quickly from illness. The others have graduated as civil servants. There are even some who deserve positions in government. Some people think that Sheikh Syaikhuna Mosque is sacred so people believe that every wish will come true. Wish itself is a promise to do something if the desired goal is achieved. The mosque is considered "a helper god". When they give up their thirst, some people bring animals and food to the mosque according to the wishes expressed. The animals that are brought to the mosque after being slaughtered in the mosque complex are boiled and then eaten with the people in the mosque.

The development of the practice of burning incense, carried out by the community in releasing their wishes in Sheikh Syeikhuna Gudang Buloh Mosque, Nagan Raya Regency, has continued for 102 years since the mosque was built in 1918. Every day, especially on Sundays, the people who have given up their desires in the Sheikh Shaykhuna Mosque keep growing. "Aside from the people of Aceh, there are also many people outside of Aceh who come to release their wishes at Gudang Buloh Mosque," said Ibrahim, who lives near the mosque.

According to Imam Chik (Grand Imam) of the Sheikh Syeikhuna Mosque, Teungku Zulkarnaini, the Gudang Mosque is fixed and has been renovated five times for more than 100 years. According to him, the benefit of burning incense is only to get rid of the smell. If there are people who come to this Gudang Mosque to use other fragrances besides the scent of incense, the scent of incense can defeat other scents by burning incense as the scent of the incense is sharper and more fragrant. 
Teungku Zulkarnaini explained that hundreds of people come to Syeikh-Syeikhuna Mosque every day, including people from outside Aceh such as Lampung, Kalimantan, Padang, and various other regions of Indonesia.

\section{Discussion}

\section{Public perception of the burning incense ritual}

The existence of culture is very important because it will aid the discussion about the existence of a society. Culture is a cultural system, activities, and physical works of humans in a society in which their emergence is achieved through a formal and informal learning process. This shows that culture will not exist by it, but rather exists because of the existence of people in the social community, so that people, society, and culture support each other. People created a culture to sustain their life on this earth because with a human culture, they will be able to fulfill their duties as caliph on this earth. With culture, human religious life will also emerge, and this makes it different from other types of creatures that exist on this earth (Sumpena, 2012: 105).

This limitation of religion as a culture is in the interest of social analysis because if religion is viewed only as dogmatic doctrine (belief), the possibility of social analysis is closed (Hafil, 2016: 168). There is a common debate in many Muslim societies about judging a particular ceremony or tradition performed by the community from generation to generation. There is a group of people who consider this tradition to be cultural, while others believe that the implementation of this tradition lies in the realm of religion (Nur, 2017: 20). On the other hand, usually as an interaction, the connection between society, culture, and religion is very close and massive. In this way, it is clear that the community becomes an issue heavily influenced by other factors when deciding what influences whom (Idrus, 2007: 398).

The positive perception of the incense ritual by the public is more likely to be embraced because people feel that they have received some of what they want after granting their wishes, which are "wrapped" in the smoked scent of the incense. In addition, the public is more confident as incense burning has been practiced at the Masjid Gudang Syeikh Syaikhuna for generations. In addition, for some people who believe in the ritual of burning incense, it is not considered a polytheistic act from a religious point of view.

The negative perception of the incense ritual arises because it is viewed as a violation of Islamic teachings, especially when incense is burned in the mosque. In Islamic leadership, praying and asking for something must not be made through an intermediary, but must ask Allah SWT directly. The presumption of bringing blessings and expecting something from objects that are considered sacred, such as mosques, is forbidden in Islam. The sacred is given by Allah SWT only to people (living beings), not to mosques (inanimate objects).

\section{Gathering and Communication Event}

Rites in Islam are all forms of religious practice in the form of religious behavior or ceremonies, the implementation of which has been arranged to be born as a form of worship, service, submission, and the expression of gratitude to a servant of the Lord to carry out His teachings and to lead a religious life in the direction of a claim to pious and piety (Ulya, 2013: 197). A ritual is a set of words, attitudes, and actions for religious believers by using certain objects (materials), tools, and implements in certain places and wearing certain clothes. Rituals or rites are performed to get plenty of blessings or nourishment from a business, such as ceremonies against reinforcements and ceremonies of birth, marriage, and death (Suprayogo, 2001: 41).

Religious and cultural values are important to be included in the national education system, because after all Indonesia is a multi-religious country and beyond that culture, culture is a characteristic of every region and ethnicity. Under other conditions, the religious discourse today is marked by concerns about the strengthening of legal-textual exclusivism, and in connection with the transnational 
Islamic ideology that is beginning to appear in public, which is very regrettable due to the development of this discourse, there is a tendency towards itself feeling uncomfortable with the existing culture in society before this discourse appeared (Marzuki, 2020: 29).

Djamaris revealed that cultural values are grouped into five relationship patterns, namely: (1) cultural values in human relationships with God, (2) cultural values in human relationships with nature, (3) cultural values in human relationships with Society, (4) cultural values in human relationships with God other or others, (5) cultural values in human relationships with oneself (Jum'addi, 2018: 153).

Community tradition is a form of a norm that is formed from below and serves as a frame of reference for action and behavior. Culture, therefore, tends to become a tradition in society, making it difficult to know the source of its origin. Hence, tradition seems to have emerged as a standardized norm in people's lives (Rahman, 2019: 349).

Traditional rituals, which are cultural heritage and social events, cannot be separated from the context of the environment and the surrounding community, as tradition can strengthen the relationship and social existence of the community. The Syeikh Syaikhuna Mosque or better known as Gudang Buloh Mosque, Ujong Pasie Village, Kuala District, Nagan Raya Regency is the place of the research. This mosque is considered sacred by some people, so most people with strong faith visit the mosque to convey their wishes.

The arrival of the community to relieve themselves in the Sheikh Syaikhuna Mosque is repeated many times. Many people come only once to convey their wishes. Before the community follows the procedure to give up their wish, people from different regions first gather in a designated place, namely in a hall within the mosque complex. In the hall, people communicate with each other and make good relationships while expressing their wishes and hopes to give up their thirst because every congregation that comes to the mosque has different desires and expectations.

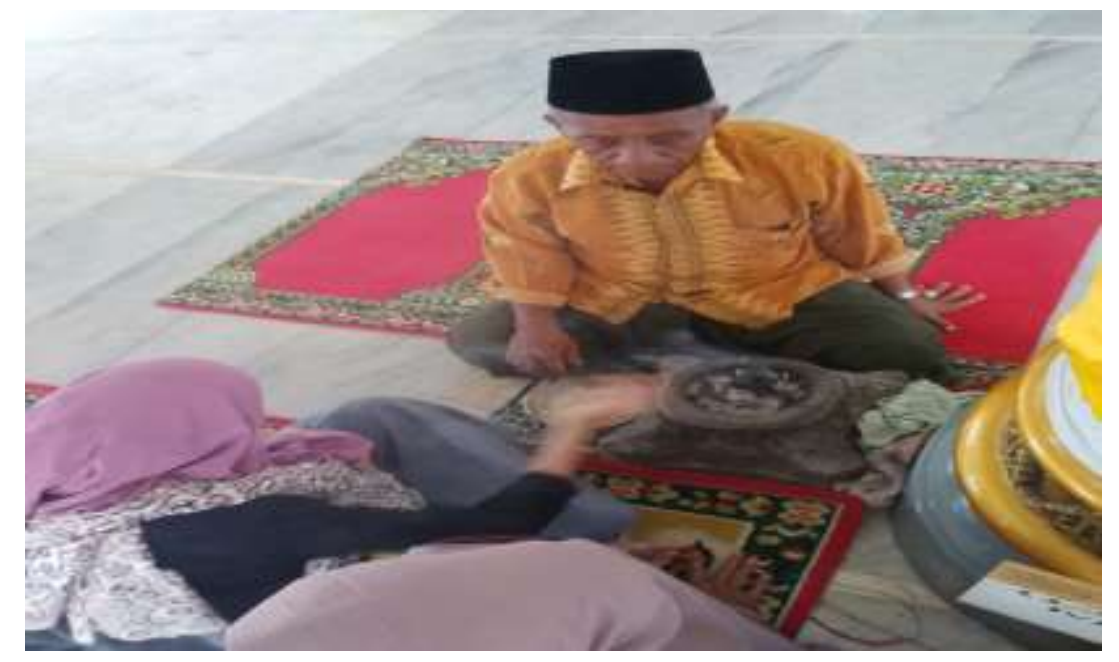

Figure 1. Tgk. Mahjali (Khadam of Syeikh Syaikhuna Mosque) is leading people to burn incense while performing their wishes.

\section{Burning Incense Procession}

Before the incense from the khadam of the mosque was burned, people who wanted to grant their wishes were asked to first convey the wish that had previously been intended and promised. Thereafter, the khadam, Teungku Mahjali, led the burning of incense. The results of an interview with Fatimah that came from Beutong, Nagan Raya Regency, said:

"My child is often sick, often cries at night, and even has difficulty sleeping. That is why we come to this mosque to grant our wish and ask for our wish to come true." 
In Sheikh Syeikhuna Mosque there is a place for burning incense near one of the pillars of the mosque. The incense gives off smoke when the incense is burned and smells great with aromatherapy. The scent of the incense is then rubbed onto the child's head. The pillar of the mosque, under which incense is placed, is tied (wrapped around) with a yellow cloth, and next to it is a donation box. The congregation then puts alms money in the donation box for those who have been treated with the scent of incense. After the procession of the burning incense, the khadam of the mosque advised the child to first cleanse (bathe) with water from the kulah (a place where washing water is located) next to the mosque.

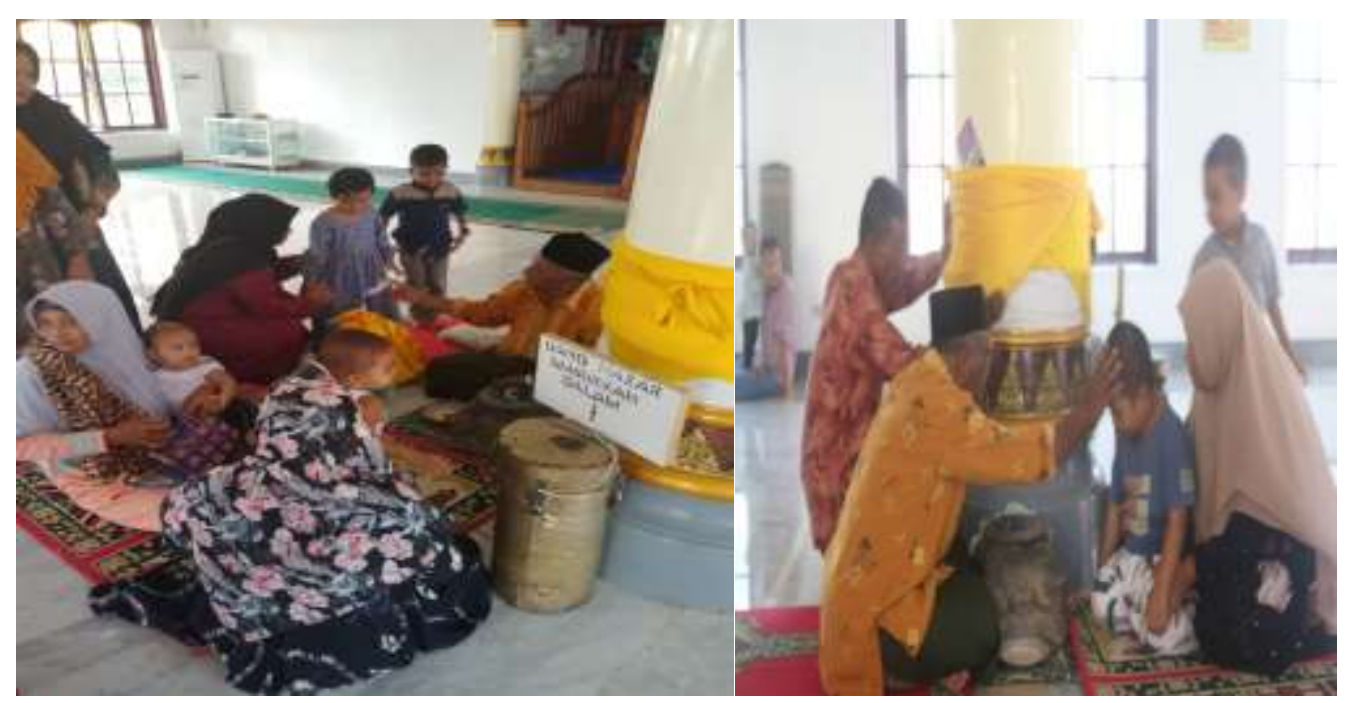

Figure 2. The ritual process of burning incense takes place

For some other people, the intention of "visiting" the Sheikh Syeikhuna Mosque is because they had a degree to graduate from a civil servant, to become the head of an office, because of the loss of property such as lost gold. "For those who go to the Sheikh Syeikhuna Mosque, the gold that has been lost can be recovered, for those who want to go to the government office, they will get the position after they return from this mosque," said Razali, a member of the community, when interviewed at the mosque.

\section{Feedback}

The incense ritual performed in the Sheikh Syaikhuna Mosque can have a direct impact on the surrounding community and on the mosque itself. From the socio-cultural area to the surrounding community, the effect of the many people who visit the mosque daily can increase the community's purchasing power for the sale of food and other goods. Also, the biggest impact is that every time the income of the Sheikh Syaikhuna Mosque increases due to the alms given by the community, especially the people who meet their needs in the mosque. In one month the amount of money (alms) can reach billions of rupiah.

\section{Conclusion}

From the above descriptions, it can be concluded that the ritual is a series of acts of sacred merit performed by Muslims using various elements and components, namely the existence of the time, place, ceremonial tools, and the people performing the ceremony. In addition, rituals also have the function of praying for a blessing or maintenance.

The meaning of burning incense ritual in the Gudang Buloh Mosque for the people of Nagan Raya Regency can be interpreted as a form of "respect" for something or an object such as a mosque or something that is considered sacred. All religions in the world have their rituals to honor their ancestors and their ancestral heritage. 
The ritual of burning incense is performed by the community as a symbol of social communication that is considered supernatural to ensure continuity and peace of life in society. The ritual of burning incense is also intended to convey human hope to God to offer protection and security to the community. Therefore, people who give up their wish in Sheikh Syeikhuna Mosque believe that it will bring blessings and their hopes will come true.

This ritual is also considered cultural heritage and social events cannot be separated from the context of the environment and the surrounding community, as tradition can strengthen friendship and social existence. Sheikh Syaikhuna Mosque is considered sacred by some people, so most of the people with strong faith visit the mosque to meet their needs.

\section{Acknowledgement}

The authors would like to thank Tgk. Mahjali (Khadam of Syeikh Syaikhuna Mosque). The authors would also like to thank all informants who cannot be mentioned individually, who were willing to openly inform about their views on the burning incense ritual in the Gudang Buloh mosque, and also about the very valuable data given for this research be completed. The authors thank the Faculty of Social and Political Sciences of Teuku Umar University for their support.

\section{References}

Aw, S. (2015). Implementasi Teori Komunikasi Sosial Budaya dalam Pembangunan Integrasi Bangsa. INFORMASI, Vol XLV (1):65-72.https://doi.org/10.21831/informasi.v45i1.7771

Aziza, Aulia. (2016). Relasi Agama dan Budaya. Alhadharah: Jurnal Ilmu Dakwah Vol. XV (30):19.https://www.researchgate.net/publication/317434093_Relasi_Agama_dan_Budaya

Bauto, L. M. (2014). Perspektif Agama Dan Kebudayaan Dalam Kehidupan Masyarakat Indonesia: $\begin{array}{llllll}\text { Suatu Tinjauan Sosiologi Agama. JPIS, } & \text { Vol } & \text { XXIII } & \text { (2):11- }\end{array}$ 25.https://doi.org/10.17509/jpis.v23i2.1616

Hadi, Amirul. (2010). Aceh: Sejarah, Budaya dan Tradisi. Jakarta:Yayasan Pustaka Obor Indonesia.

Hafil, Ach Shodiqil. (2016) Komunikasi Agama Dan Budaya (Studi atas Budaya Kompolan Sabellesen Berdhikir Tarekat Qadiriyah Naqshabandiyah di Bluto Sumenep Madura). Al-Balaq: $\begin{array}{lllll}\text { Jurnal Dakwah Komunikasi, } & \text { Vol }\end{array}$ 182.https://ejournal.iainsurakarta.ac.id/index.php/al-balagh/article/download/350/115

Harahap, M.I.T, dan Harahap, E.M. (2019). Pengalaman Masyarakat Pakpak Bharat Merawat Luka Menggunakan Kemenyan. Jurnal Maternitas Kebidanan, Vol IV (2):6272.https://doi.org/10.34012/jumkep.v4i2.736

Idrus, Muhammad. (2007). Makna Agama dan Budaya bagi Orang Jawa. UNISIA, Vol. XXX (66):391401.https://journal.uii.ac.id/Unisia/article/download/2683/2462

Jum'addi. (2018). Strategi Majelis Adat Aceh (MAA) dalam Melestarikan Budaya Aceh. Al-Idarah, Vol. II (2):147-166.https://jurnal.ar-raniry.ac.id/index.php/alidarah/article/download/4422/pdf

Koentjaningrat. (2009). Pengantar Ilmu Antropologi (Cetakan 2). Jakarta: Rineka Cipta.

Marzuki, Angga. (2020). Nilai Agama dan Budaya dalam Tradisi Besaman. Ushuluna: Jurnal Ilmu Ushuluddin, Vol. IV (1):19-32.http://journal.uinjkt.ac.id/index.php/una/article/view/15758

Nur, Aslam. (2017). Garis Batas Antara Agama dan Budaya Dalam Perspektif Antropologi. ADABIYA, Volume XIX raniry.ac.id/index.php/adabiya/article/download/7484/4457

Nurdin, Abidin. (2013). Revitalisasi Kearifan Lokal di Aceh: Peran Budaya dalam Menyelesaikan Konflik Masyarakat. Analisis, $\quad$ Vol. $\quad$ XIII (1):135-154. https://media.neliti.com/media/publications/57556-ID-revitalisasi-kearifan-lokal-di-acehpera.pdf

Rahman, Fachrir (2019). Patuq dalam Tradisi Kematian Masyarakat Desa Kuta (Sebuah Tinjauan Antropologi Hukum Islam). Samarah: Jurnal Hukum Keluarga dan Hukum Islam, Vol.III (2):341-364.https://jurnal.ar-raniry.ac.id/index.php/samarah/article/download/3925/3554 
Setiawati, Rahmi. (2019) Makna Komunikasi Ritual "Sedekah Laut" Sebagai Pelestarian Nilai-Nilai Budaya Maritim Masyarakat Desa Pulau Kelapa-Kepulauan Seribu. Proceeding Seminar Nasional Teknologi Terapan Inovasi Dan Rekayasa (Snt2ir) 2019 Program Pendidikan Vokasi Universitas Halu Oleo: (436-446). http://ojs.uho.ac.id/index.php/snt2bkl/article/view/9873

Sumpena, Deden. (2012). Islam dan Budaya Lokal: Kajian terhadap Interelasi Islam dan Budaya Sunda. Jurnal Ilmu Dakwah Vol. 6 (19):101-120. https://media.neliti.com/media/publications/63623-ID-islam-dan-budaya-lokal-kajian-terhadapi.pdf

Suprayogo, I. (2001). Metodologi Penelitian Sosial-Agama. Bandung: Remaja Rosda Karya.

Susanti, L. (2018). A Tradition of Fuel Incenses in People's Life at Nagari Sabu Kecamatan Batipuh Kabupaten Tanah Datar. JOM FISIP, https://jom.unri.ac.id/index.php/JOMFSIP/article/view/17255

Sztompka, Piotr. (2008).Sosiologi Perubahan Sosial. Jakarta: Prenada.

Tilaar, H.A.R. (1999). Pendidikan Kebudayaan dan Masyarakat Madani Indonesian. Bandung: Remaja Rosda Karya.

Ulya. (2013). Ritus dalam Keberagamaan Islam: Relevansi Ritus dalam Kehidupan Masa Kini. Fikrah, Vol I (1):195-206.http://dx.doi.org/10.21043/fikrah.v1i1.312. 